\title{
Prominence in Indonesian
}

\author{
Stress, phrases, and boundaries
}

\author{
ELLEN VAN ZANTEN AND ROB GOEDEMANS
}

\begin{abstract}
Many (Western) languages have word-based stress, which entails that one, predictable syllable per word is more prominent than all the other syllables in that word. Some linguists claim that such stresses also occur in Indonesian. In this article, we set out to investigate that claim using experimental, phonetic methods. The results confirm our hypothesis that Indonesian lacks word-based stress. Yet, we do observe some kind of prominence pattern. In the last part of this article, we search for the phonological phenomenon that generates this pattern, exploring the level of the phrase to see whether phrasal accents or boundary markers are likely candidates.
\end{abstract}

KEYWORDS

Indonesian, phonetics, prominence, stress, accent, and boundary tone.

\section{INTRODUCTION $^{1}$}

In many course books for Dutch learners of Indonesian (see Teeuw 1984; Steinhauer 2001), you will find a short paragraph about word stress roughly stating that "stress is on the penultimate syllable unless the vowel in the penultimate syllable is schwa (pepet), in which case stress is final". This implies that, for instance, garúda ( $\bar{u}$ indicating stress) is the correct way to pronounce

1 We would like to thank in particular Herman Poelman and the staff of the Erasmus Huis Taalcentrum in Jakarta for running some of the perception experiments.

ELLEN VAN ZANTEN is a guest researcher at the Phonetics Laboratory, Leiden University. Her main interest is in the shape and function of prosody of Indonesian languages in particular. Together with Harry van der Hulst and Rob Goedemans, she is currently preparing "Stress patterns of the world; The data". E-mail: E.A.van.Zanten@hum.leidenuniv.nl.

ROB GOEDEMANS is editor-in-chief for web communications as well as ICT-in-education consultant for the Faculty of Humanities at Leiden University. In the recent past, he conducted research in the phonetics and phonology of stress. When regarding the Indonesian language, the research was conducted with Ellen van Zanten. On a small scale, he is still active in typological investigations into the variety and patterning of word stress. E-mail: R.W.N.Goedemans@ hum.leidenuniv.nl.

(C) 2009 Fakultas Ilmu Pengetahuan Budaya, Universitas Indonesia 
the Indonesian word for eagle. Strangely enough, this almost absolute certainty about the location of stress in Indonesian is only reflected in some theoretical articles about the phonological derivation of word stress in Indonesian (for example, Cohn 1989; Cohn and McCarthy 1994). Most primary descriptive sources we know of are much less resolute in their claims regarding the location of word stress (see Halim 1974), make a different claim (see Samsuri 1971: stress is final) or confirm that the rule given above is a tendency, but not an absolute fixed rule (see Laksman 1994). Some authors, like De Hollander (1984: 27-28) and Alieva et al. (1991:64) claim that, in some cases, stress is maintained on the penultimate syllable of the base word when a suffix is attached to it (for example, bántuan vs. bantúan 'assistance', pernyátaan vs. pernyatáan 'declaration, expression'. Moreover, with respect to the stress ability of the schwa, Van Zanten and Van Heuven (2004: 10) found that stress on the first, second or third syllable were all quite acceptable for sebelum / səbəlum/ 'before'. Stress on the prefinal syllable was preferred only when this syllable was heavy, as in anaknya 'his child'.

Uncertainty concerning stress position in Indonesian seems to be reflected in difficulties that speakers of Indonesian have with word stress when learning a foreign language. For instance, it is by no means uncommon to hear Indonesian speakers, otherwise extremely fluent in Dutch, make surprising (for their level of command) mistakes in the stressing of Dutch words. One could hear them say inpákken 'to wrap up' and Goedemáns 'a family name' just as easily as the correct forms inpakken and Góedemans.

Given the fact that a basic characteristic of word stress is that it always occurs on one and the same syllable of a given word, we may wonder about the linguistic reality of this phenomenon for speakers of Indonesian, and ask ourselves the fundamental question: Does word stress exist at all in Indonesian? To understand the ins and outs of this question, and the details of the experiment we conducted to answer it, we must first make a little digression into the phonetic and phonological background of the phenomena we know as stress and accent.

\subsection{WORD STRESS: BACKGROUND}

In many languages, the syllables that form words are not all equally "strong". Often, some of them are heard as longer, louder, clearer or higher in pitch than the others. Usually, one of the syllables in a given word is the most salient (prominent) because it outclasses all the others in one or more of the aforementioned phonetic properties. This single syllable is said to bear the "main stress". In some, but by no means all, stress languages, a further division can be made with respect to the rest of the syllables in the word. The more salient of these carry "secondary stress" while others are unstressed.

In the majority of the languages that feature stress, the patterns of main and secondary stresses we observe in the words are far from random. The location for main stress is usually limited to one (or a few) preferred position(s) in a given language, and secondary stress (also known as rhythm) usually 
alternates (strong - weak or weak - strong) over the rest of the syllables. This hints at organization on a linguistic level. Word stress in these languages is governed by rules that predict the location of the main and the secondary stresses for most (but not necessarily all, see below) of the words in the language. The speakers of the language know these rules subconsciously.

In the remainder of this article, we will focus on main stress only. We will not go too deeply into "metrical phonology", the phonological theory that deals with the set of rules that derives all the possible stress patterns of natural languages. We simply say that such rules exist, and that they prescribe a single location for main stress in (most of) the words in the language.

The rules usually refer to the edges of the word and/or the internal make-up of the syllables to determine that location. In Yimas (Foley 1991), for instance, stress is invariably located on the first syllable of the word, while in Murik (Abbot 1985) stress is located on the first syllable of the word that contains a long vowel, or the first syllable of the word when there are no long vowels; see the examples in (1):

(1)

\begin{tabular}{|c|c|}
\hline Yimas & \\
\hline 'awtmaypi & 'sugarcane' \\
\hline 'yamparan & 'stand up' \\
\hline
\end{tabular}

\section{Murik}

$\begin{array}{ll}\text { anənp }^{\text {ha'ř }}: t^{\text {h }} & \text { 'lightning' } \\ \text { 'nungunsařagat } & \text { 'green' }\end{array}$

In some languages, not all the words have predictable, rule-based stress. Speakers of such languages must learn the stress locations of these so-called "lexically stressed" words. In every case, however, whether stress is lexical or predictable by rules, the main stress for any given word is on exactly the same syllable every time a speaker pronounces that word. ${ }^{2}$

With this remark, we touch upon a universal principle that governs the rules of metrical phonology. Stress rules conspire to select one and only one syllable to act as the head of the word. A second universal is that there can be only one head. The rules thus lead to exactly the same syllable every time they are applied to a given lexical element. Therefore, if we observe languages in which many words show variation in the syllable that is selected for main stress we must doubt whether rules were applied at all. If we are in doubt about the application of rules, we should be in doubt about the phenomenon we are dealing with, because stress and rules are inseparable partners.

Yet, we do hear some form of syllable prominence when we listen to Indonesian speech. Suppose we are indeed dealing with a language that has no rules, and therefore, no stress. Then what could be the phenomenon that governs the prominence we hear? To answer this question, we must separate the wordbased phenomenon of stress from phrase-based phenomena like accent.

2 Readers who are interested in the exact details concerning these rules are referred to Hayes' (1995) excellent expose of stress parameters, or to, for instance, Goedemans, Van der Hulst, and Visch (1996). 


\subsection{ACCENT}

As mentioned in the previous section, the phonetic correlates of stress, as first defined by Fry $(1955,1958,1965)$ are pitch, intensity ('loudness'), duration and vowel quality. However, pitch is also the phonetic cue for intonation, in which accent is one of the key players. The speaker, to signal to the listener that some part of the utterance contains new information, can, for instance, use accent. The accented part is said to be in focus (Ladd 1980). In English, the accent is realized by a pitch movement on the prosodic head of the focus domain (Bolinger 1958), like in (2) where coffee is in focus; an accent-lending pitch movement should be steep, sufficiently large and in a specific position in the (stressed) syllable (Van Heuven 1994: 19).

$$
\begin{aligned}
& \text { What did you say? } \\
& \text { I said [coffee }]_{+F}
\end{aligned}
$$

The accent in (2) occurs on the first syllable of coffee, as this syllable carries the main stress and is, therefore, the prosodic head of the word. We see here that the stressed syllable serves as the "docking station" for the accent. In fact, stress and accent co-occur so frequently that the cue for accent, pitch, can easily, mistakenly, be interpreted as a cue for stress. To differentiate between stress cues and accent cues we investigate examples like (3). In (3a) we see a sentence in which the word coffee is not in focus, and therefore, does not carry an accent; the accent is on say and write. However, the syllable [cof] is stressed, as in (2). Speakers of English have no difficulties whatsoever in identifying this stressed, but unaccented, syllable of the word coffee in (3a), since the other stress cues, of which duration is the most salient, are still clearly perceptible.

$$
\begin{aligned}
& \text { a. I told you to }[\text { say }]_{+F} \text { coffee, not }[\text { write }]_{+F} \text { it } \\
& \text { b. I wrote }[\text { tof }]_{+F} \text { fee not }[\text { cof }]_{+F} \text { fee } \\
& \text { c. Now I heard cof }[\text { fin }]_{+F} \text { not cof }[\text { fee }]_{+F}
\end{aligned}
$$

In English, single syllables can be in focus and thus accented when we contrast two smaller items in one sentence, like in (3b). Finally, (3c) shows that even unstressed syllables can be in focus and carry an accent. These examples show that pitch is crucially tied to the intonation of the sentence and is therefore not a necessary cue for stress. Therefore, we must follow Bolinger's (1972) claim that we are dealing with two separate linguistic phenomena here.

Now that we have established accent as a linguistic phenomenon in its own right, with its own phonetic cue, and have even seen that it can occur, albeit under special circumstances, in its own location, away from the stressed syllable, we may speculate on the phenomenon we encounter in Indonesian. Could it be accent? Could its position fluctuate so much because there is no stressed syllable so that the accent cannot find a docking station? Intriguing speculations, but we can only start to look into them seriously once we have firmly established the status of Indonesian as a language without stress. In the 
next section, we will describe the steps we took to check whether Indonesian stress is fact or fiction.

\section{EXPERIMENTS INTO THE NATURE OF INDONESIAN "STRESS"}

As we have seen above, a very confusing picture emerges when one consults reports on stress in Indonesian. We set out to sketch a clearer picture by way of experimental research. Our first aim was to determine whether the location of stress in Indonesian is mainly penultimate, as proposed in the traditional literature, whether it is located somewhere else in the word, or even truly free, as our own observations seemed to suggest. To this end, we gathered speech materials in recording sessions with native speakers of Indonesian. In the materials thus obtained, we measured intensity, pitch, and duration in all the syllables. If one of the syllables in these words is perceptually more important, then measurements for that syllable should show consistently higher values for one or more of these three properties when compared to the other syllables in the word. We also hoped that the composition and behaviour of the three cues in these materials would tell us whether we are dealing with stress, accent, or both, or with yet another phenomenon.

We included regional background as a variable in the experiment and looked at the speech of two speakers. The first speaker's substrate language, Javanese, is said to contain only weak stresses, the location of which is a matter of debate. Some sources compare Javanese stress to Indonesian stress, since it has a weakly stressed penultimate syllable, unless this syllable contains a schwa, in which case stress is shifted to the final syllable (Ras 1982: 13). Poedjosoedarmo, on the other hand, suggests that stress is final in Javanese (Poedjosoedarmo 1982: 49; footnote 45), while Horne (1961: 26) claims that "it does not matter which syllable in a Javanese word gets the loudest stress". More recently, Stoel (2006) suggests that Banyumas Javanese does not have word-level stress. The second speaker's substrate language, Toba Batak, is one in which we find clearly defined stresses. This language is prosodically quite different from Javanese, because stress can be contrastive, and the stressed syllable - usually the penult - is very clearly marked by the prosodic cues we introduced above (Nababan 1981: 27, 135; Percival 1981: 42-44; for an overview of the literature see Roosman 2006, 2007).

We expected these differences in substrate-language stressing to influence the way in which these speakers pronounce Indonesian words.

\subsection{PRODUCTION EXPERIMENTS}

\subsubsection{METHOD}

For the production experiment, we selected the words in (4).

$\begin{array}{llll}\text { masyarakat } & \text { 'society' } & \text { kacamata } & \text { 'spectacles' } \\ \text { laksamana } & \text { 'admiral' } & \text { dikatakan } & \text { 'it was said' } \\ \text { perempuan } & \text { 'woman' } & \text { cendekia } & \text { 'clever' }\end{array}$


These words were embedded in the sentence Dia mengucapkan kata (masyarakat) 'He pronounces the word (masyarakat)'. As such they were in sentence-final, [+focus] position and should receive an accent (marked by a pitch movement) on the stressed syllable (Van Heuven 1994: 15, see also Samsuri 1978). We also wanted to measure the three prominence cues in the same words when they were not accented. In such a way we should be able to determine the influence of accent on the phonetic cues. Hence, the words in (4) were also embedded in non-final and non-focus position in the sentence: Kata (masyarakat) itu tepat 'The word (masyarakat) is correct'. In this case we expected tepat to receive the accent.

The resulting sentences were each read twice by two male Indonesian speakers. As mentioned above, one of the speakers had a Javanese language background while the other speaker was a Toba Batak speaker.

\subsubsection{RESULTS AND DISCUSSION}

When looking at the recorded speech of the Toba Batak speaker, it struck us that the prefinal syllable was always significantly longer and louder than the other syllables. It did not matter whether the word was pronounced in + focus position or not. There was always an increase in intensity and duration. The average duration of vowels in prominent syllables was approximately $50 \%$ longer than the average duration of vowels in non-prominent syllables. For consonants, lengthening was around $25 \%$. Such lengthening effects were also attested for Toba Batak speakers by Van Zanten and Van Heuven (1997: 210211); they fit in well with data on (stress) languages like English and Dutch (see Nooteboom 1972; Eefting 1991). Peak intensity of vowels in prominent syllables was $2.5 \mathrm{~dB}$ (decibel) higher, on average, than in the non-prominent vowels in the Toba Batak speech data. In our targets, it was always the penultimate syllable that was made prominent in this way. As far as pitch was concerned, there was, as expected, no pitch movement when the words were pronounced in a non-focus position (in Kata [masyarakat] itu tepat). When the words were pronounced in focus (in Dia mengucapkan kata [masyarakat]), we did find a pitch movement, again as expected. The shape of the pitch contour was robust enough to be interpreted as a cue for accent, according to criteria set by Van Heuven (1994: 19) with respect to size, steepness and position in the syllable. In Figure 1, we present the oscillogram and intonation contour of kacamata as spoken by the Toba Batak speaker in and out of focus, as an example.

For the Javanese speaker a very different pattern emerged. We could not find duration or intensity patterns that pointed in the direction of penultimate stress. On the contrary, the second syllable, considered to be unstressed in all the reports we know of, was often longer than the other syllables in words in [+focus] position. For the pitch cue, we only found a small rise on the first syllable, and a relatively large pitch fall which started somewhere near the boundary between the prefinal and the final syllable (see also Ebing 1997); this apparently common Indonesian pitch contour is also reported in Van Zanten and Van Heuven (2004). Neither pitch rise nor fall meet Van Heuven's criteria 
for accent perception in stress languages. However, when listening to the recordings, we perceived, with our non-native ears, either a prominent final or prefinal syllable, depending on the syllable in which the fall started.

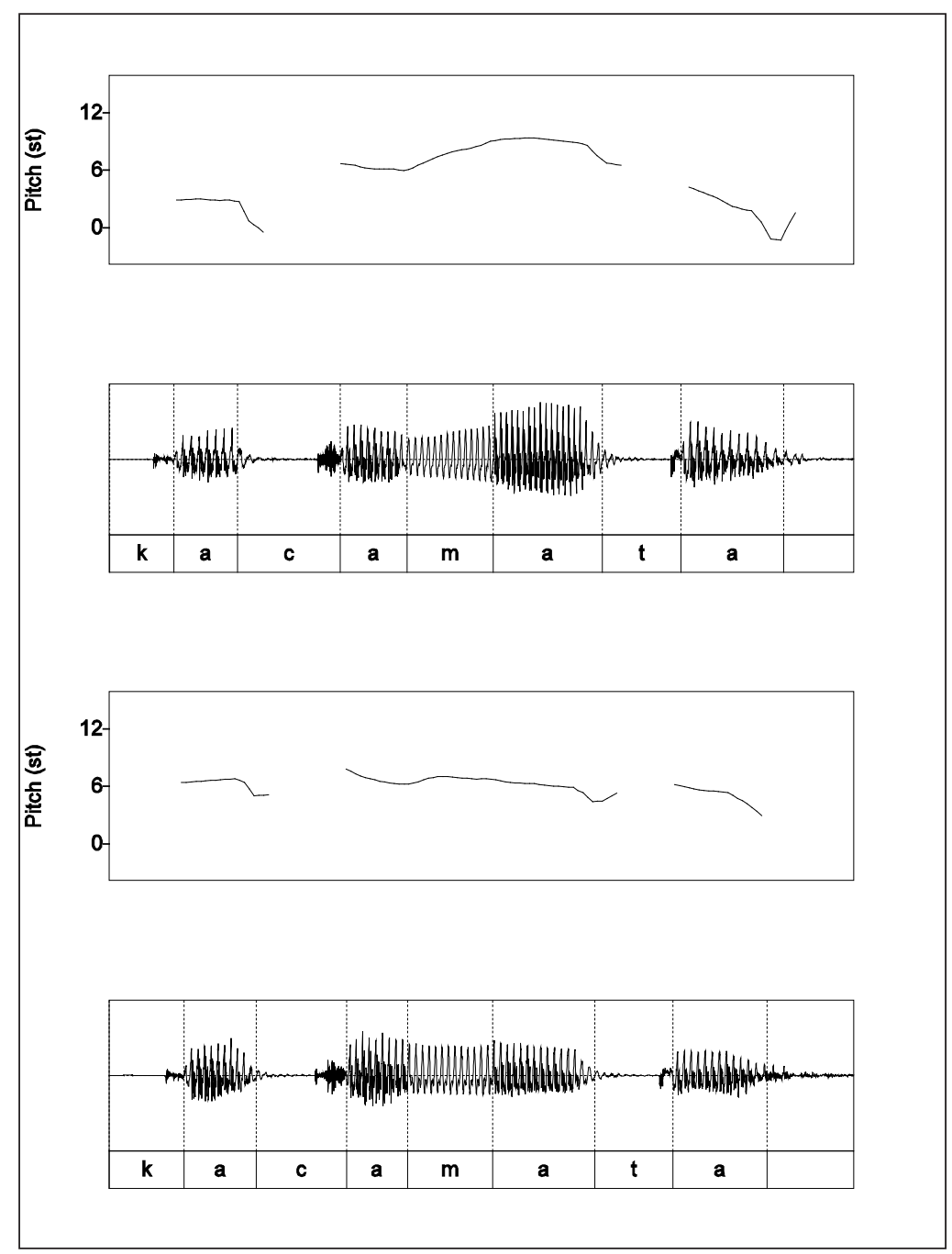

Figure 1: Oscillograms and original intonation contours for kacamata as produced by the Toba Batak speaker, in focus, (top) and out of focus (bottom)

For sentences in which the target words were out of focus, no correlates of word-level prominence were found. The only salient feature we found was a considerable pitch rise on the prefinal syllable. This pitch movement is part of a phrase intonation contour, which ends at the phrase boundary between itu and tepat. Figure 2 contains oscillograms and intonation contours for kacamata as spoken by the Javanese speaker in and out of focus, as an example.

We have seen that the acoustic properties that we can relate to prominent syllables in Indonesian as spoken by a Toba Batak and a Javanese speaker 
differ greatly. For the Toba Batak speaker we measured steep and sharply defined pitch movements as well as duration and loudness effects, which could be related to word stress, but also to accent at the phrase level. In the utterances of the Javanese speaker, we only found evidence for accent at the phrase level (in the form of pitch movements). No acoustic correlates for word stress played a role in his speech. The properties behave in a more or less predictable fashion; remember that we already voiced the expectation that the speakers would use prosodic patterns from their substrate languages in their production of Indonesian. As noted above, Toba Batak is a stress language, while Javanese has either only a weak stress, or no stress at all.

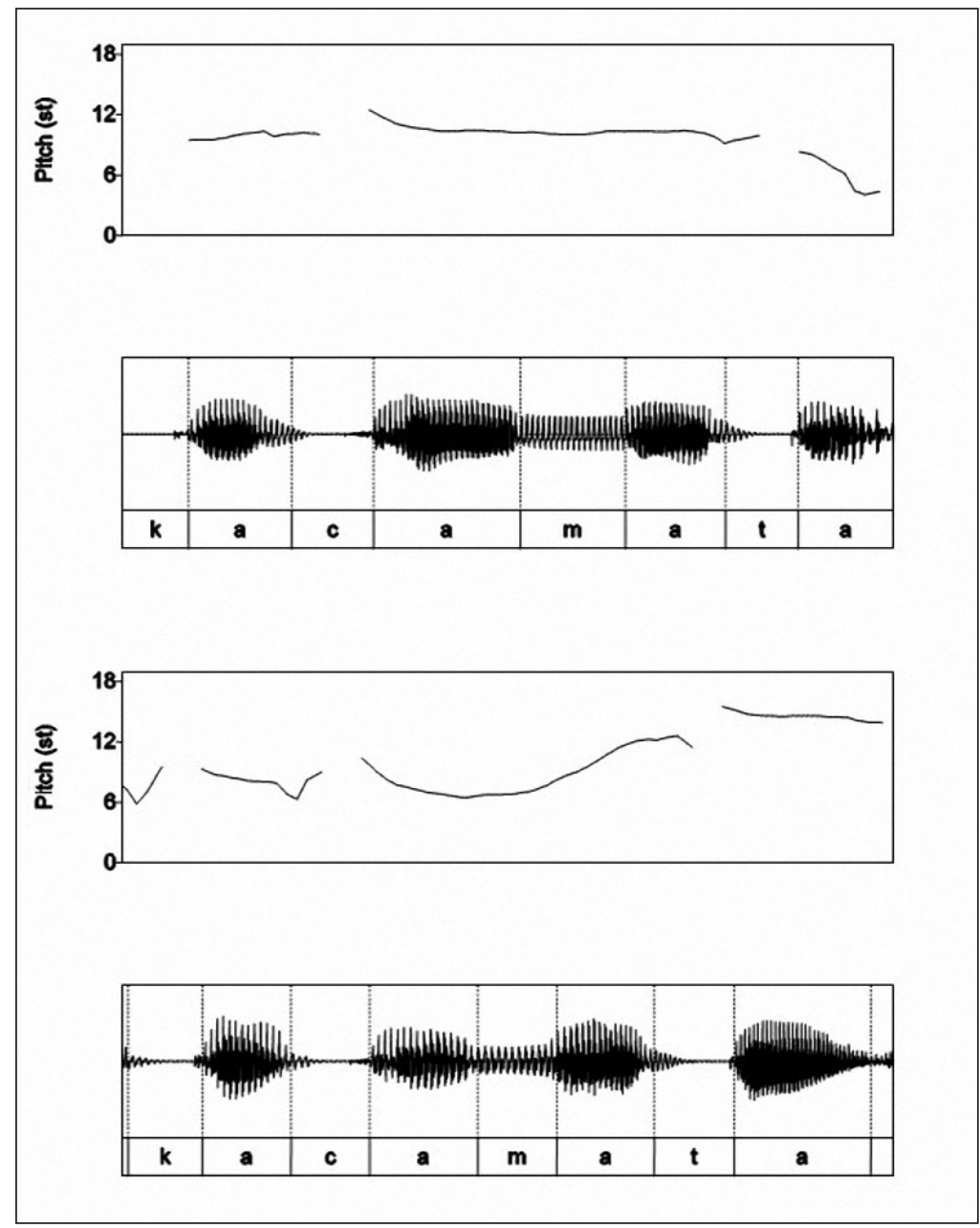

Figure 2: Oscillograms and original intonation contours for kacamata as produced by the Javanese speaker, in focus, (top) and out of focus (bottom)

For now, we conclude that the variety of Indonesian as spoken by the Toba Batak speaker shows clear signs of stress as a factor in play, while in the variety produced by the Javanese speaker stress is absent. However, we must 
not be too hasty. Remember the discussion on "docking stations" in Section 1.1. Stress is the "anchor" for accent, and accent seems to be a phenomenon we do find in the Javanese speaker's recordings. What if a language chose not to mark stressed syllables with prosodic cues like duration and intensity at all, but that in this language the accent would always, unerringly, align to the penultimate syllable? That should surely mean that the penultimate syllable is a predictable docking station, and that is tantamount to saying the syllable is stressed, albeit not overtly marked as such by phonetic stress cues. In the next section, we will look at some perception experiments we devised to determine whether we are, in fact, dealing with such non-overt stresses in the Javanese speaker's Indonesian, or whether it is indeed stressless.

We conclude this section with a note of caution. In our discussion of the theory behind the separation of stress and accent, we have noted that intensity and duration are cues for stress, and that pitch is the cue for accent. However, there can be no stressing without at least a small rise in pitch, and as a matter of course, accented words are pronounced more precisely, and therefore often a bit longer and louder than unaccented words (see Eefting 1991). We have not elaborated upon these observations in the discussion of our data, but they were clearly present. What we mean to say here is that one must only draw conclusions from clearly measurable recurring patterns in a careful comparison of words pronounced in and out of focus. If one does not, misinterpretations can be the result. Lengthening of syllables in words pronounced in focus position, for instance, does not necessarily reflect stressing. It could just be the lengthening effect of the accent one is looking at. Only if the same syllable of the same word, placed in a sentence where it is out of focus, shows a similar (percentage-wise) and consistent lengthening effect, one may safely assume to be dealing with stress.

\subsection{PERCEPTION EXPERIMENTS}

The differences that languages and dialects show in their realization of stress force us to be cautious in drawing hard and fast conclusions based on impressionistic data, or only from a production experiment. In case the stress rule in the researcher's mother tongue differs from the rule in the language he investigates (which may even have no word-based stress at all), the perception of the linguist may be coloured by the stress rule in his own language. In this light, it seems appropriate to perceptually test the native speakers' intuition on stress position. Such intuitions have to result from carefully controlled perception experiments in which judgements are indirectly obtained (see Berinstein 1979). In the perception experiments presented in this article we use two experimental paradigms in which we obtain such indirect native speaker judgements from Indonesian listeners for a variety of prominence patterns.

In the first test, Indonesian listeners with the same regional backgrounds as our two speakers are asked to indicate which one of two prominence patterns they prefer in the speech of both speakers. The second test is an evaluation test in which the same listeners are asked to rate the acceptability of different 
prominence patterns, again for both speakers.

For both tests we created various artificial "stress" locations to determine whether there are underlying stresses in Indonesian to which accents align. We have clear expectations as to which variety may ("Toba Batak"), and which may not ("Javanese") have stress, so we use both for the sake of comparison. As we mentioned above, the target location for accent alignment is the stressed syllable. If there is such a stressed syllable, the accent will align to it and Indonesian listeners should prefer the accent to be located on this one particular syllable. If we (artificially) vary the location of the accent, and, in doing so, reveal indifference of Indonesian listeners with respect to this variation, then there is no preferred syllable for the accent. If that is the case, as we suspect it will be for the Javanese-based speech, the last reason to adopt stress for this variety of Indonesian vanishes. Obviously, no abstractly defined (stress) location for accent alignment will be needed in that case, and we have already seen above that there are no phonetic correlates of stress forcing us to adopt an underlying phonological phenomenon. If, on the other hand, test words are preferred and judged more acceptable when prominence is realized on the prefinal syllable, we will conclude that the traditional rule for Indonesian (stress is located on the prefinal syllable) holds true.

With respect to the Toba Batak variety, we wish to verify whether the prominence patterns found in Section 2 really reflect word stress. If listeners are indifferent to our induced variation in the location of stresses in the Javanese variety, it will be interesting to see how they react to such variation in the Toba Batak variety, as that one shows clear indications of stressing.

\subsubsection{STIMULI}

The two perception experiments were carried out with the six four-syllable words in (4) which were manipulated in accordance with our findings regarding stress and accent properties in the production data. We constructed two sets of stimuli, one based on the production of the target words by the Toba Batak speaker, the other based on the utterances of the Javanese speaker.

Since we can only find stress positions in Javanese Indonesian through accent location, there is no point in considering the [-focus] condition in our perception experiments. Only in the [+focus] condition will the stressed syllable be accented. Hence, in the perception experiments, which will be discussed in the next section, we will place all the target words in final [+focus] position of the carrier sentence (Dia mengucapkan kata ...).

In order to investigate which of the variable stress positions in Indonesian words were acceptable for Indonesian listeners we chose to make pairs of stimuli. In every case we paired a manipulated word with prominence properties on the prefinal syllable (namely stressed according to the traditional rule; for example, masyarákat) with a word in which the acoustic properties of prominence were artificially transferred to one of the other syllables (másyarakat, masyárakat, and masyarakát). Hence, we had to create four such stimuli for each word. In addition, we created one stimulus per test word, in 
which none of the syllables carried prominence properties, but in which the first syllable of the preceding word káta did. We expected this " 0 " stimulus to receive low scores in the tests. So, altogether five stimuli were created for each word. On top of that, we created "close copy" versions of the original six 'Javanese' test words, in which the pitch fall occurred at the boundary between the penultimate and the final syllable. In close copy versions the pitch contours are simplified using speech processing software, but these versions sound exactly the same as the originals. To reduce the workload on the listeners, the first part of the carrier sentences (Dia mengucapkan) was deleted.

\subsubsection{EXPERIMENTAL PARADIGMS}

Two different listening experiments were conducted. The first was a comparison experiment in which subjects were requested to choose between two members of a stimulus pair. As noted above, each pair consisted of a reference stimulus with prominent prefinal syllable, and any one of the five ('Toba-Batak') or six ('Javanese') versions of the same target word.

Secondly, we devised an evaluation test in which subjects were to judge the acceptability of the individual stimuli.

\subsubsection{LISTENERS AND PROCEDURE}

Two groups of Indonesians took part in the listening experiments. These groups were selected to match the substrate languages of the original speakers, that is a group of 20 speakers of Indonesian who had Javanese as a substrate language, and a group of 13 Indonesian speakers with a Toba Batak substrate. ${ }^{3}$

Eleven listeners were tested individually at the Phonetics Laboratory of Leiden University and the remainder was tested in two groups in the Erasmus House language laboratory in Jakarta. Subjects were told that they were going to listen to the final parts of declarative sentences and that these had different intonations (lagu kalimat). They were not informed about the actual purpose of the experiments, that is to compare the acceptability of different stress patterns. For the paired comparison test, listeners were asked to indicate on their answer sheets which of each pair they preferred. It was made clear to them that they had to make a single choice in all cases; blanks were not allowed. For the acceptability test, subjects were instructed to rate the acceptability of each phrase on a ten point scale, ranging from 1 ("very bad") to 10 ("very good"). They were requested to encircle the appropriate mark on the answer sheets for each stimulus phrase. Each test was preceded by three practice items. After this, the tape was stopped to answer any questions raised by the listeners. After every ten items a short beep was inserted to help the listeners keep track of the stimuli on their answer sheets. All instructions

3 A report on the reactions of a group of Jakartan listeners to these stimuli can be found in Van Zanten, Goedemans and Pacilly (2003). The results for the Jakartan listeners largely coincide with the results for the Javanese listeners presented below. 
were in Indonesian. Approximately half of the subjects (that is, half of each listener group) listened to the "Javanese" stimuli first and then to the "Toba Batak" stimuli. The comparison test preceded the acceptability test. The other subjects were presented with the "Toba Batak" stimuli before listening to the "Javanese" stimuli; again, the comparison test was followed by the acceptability test.

\section{RESULTS AND DISCUSSION}

\subsection{JAVANESE-BASED STIMULI}

\subsubsection{COMPARISON EXPERIMENT}

In the comparison experiment, a stimulus with prominence in penultimate position was paired with one of the artificial variants we created and which had prominence on one of the other syllables. As stated above, we asked listeners to select the stimulus from the pair that sounded better. For each substrate listener group, and all possible prominence positions, we calculated the percentage of responses in which the subjects chose the stimulus that did not have prominence on the penultimate syllable as the better one of the pair. In some of our pairs the stimuli were identical (namely the penultimate syllable was prominent in both words). In that case, the listeners should be unable to perceive any difference and select each word in exactly $50 \%$ of the cases. ${ }^{4}$

If Indonesian does indeed have penultimate stress, a stimulus with prominence on a syllable other than the penult should score low when compared to a stimulus in which prominence is penultimate, hence for these stimuli the score should lie well below the $50 \%$ mark; stimuli with penultimate prominence should be selected as the better one of the pair.

In this article, we will disregard any differences between the six individual stimulus words. In Figure 3, we present the results for the two groups of listeners and the Javanese-based stimuli. In this figure, the percentage scores for the words that did not have prominence on the penultimate syllable (Scomp) are plotted along the y-axis, and the prominence locations (syllable number) are placed on the $\mathrm{x}$-axis (in the " 0 " case, the first syllable of káta is the prominent one; "S" represents the stylized "close copy" version of the original utterance). The scores for each of the two substrate groups are connected by lines.

We observe that the data points for the Javanese listeners do not follow the pattern we expect to see for a language in which prominence (stress) is fixed on the penultimate syllable. In that case, position 3 (the penult) should get a $50 \%$ score while the rest should remain well below the $50 \%$ line. For the Javanese listeners, prominence on the final syllable is judged as acceptable as prominence on the penultimate syllable. We leave it at that observation

4 In practice, however, subjects tend to choose the first member of a pair when they are unable to make a motivated choice. This bias for the left-hand member of a stimulus pair is known as the Time Order Error (TOE; see Woodrow 1951; Van Heuven and Van de Broecke 1982). In our experiments we tried to eliminate the TOE effect by presenting the stimuli to the subjects in both orders. 
for now and postpone the discussion of the status of prominence in Javanese Indonesian to Section 5.1. We find the same general pattern for the Toba Batak listeners. Both final and prefinal prominence are acceptable, but prominence on the first or second syllable (or none at all) is not.

For the three versions that get lower scores, prominence on the second syllable of the test word seems to be slightly more acceptable than prominence on the first syllable for the Javanese listeners. We do not yet know whether this tendency is linguistically relevant. For the two syllables with higher scores, the Javanese listeners, as opposed to the Toba Batak listeners, seem to even prefer prominent final syllables over prominent penultimate ones. This goes against the claim that stress is predominantly penultimate in Indonesian. Finally, the two groups of listeners both judge the words with penultimate or final prominence to be approximately as acceptable as our stylized version of the Javanese pitch contour in which the pitch fall started somewhere in the border region between prefinal and final syllable. We take this as an indication that the exact position of the fall does not matter. Also, apparently, our manipulated words sounded sufficiently natural to Indonesian ears.

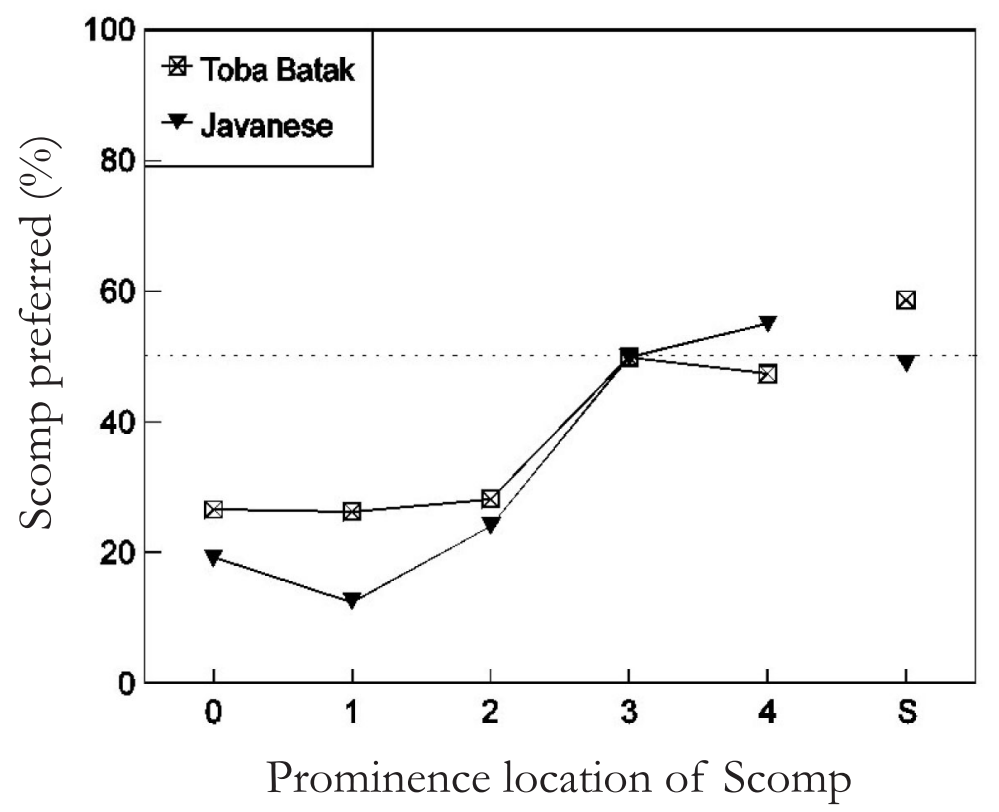

Figure 3: Javanese-based stimuli. Percentage of cases in which the stimulus with nonpenultimate prominence (Scomp) was judged better than the one with penultimate prominence. Broken down by prominence location and substrate listener group.

So far, the evidence we have found argues against the claim that stress is predominantly penultimate in Indonesian. Let us now look at the data from our acceptability test to see whether these point in the same direction. 


\subsubsection{ACCEPTABILITY TEST}

Figure 4 shows the means of the scores (represented on a scale from 1 to 10 on the y-axis) the listeners gave for each stimulus (so, for all prominence locations, represented on the $\mathrm{x}$-axis), again broken down by substrate group, as in Figure 3.

The lines connecting the scores for each group largely follow the same pattern as those in Figure 3. Prominence locations " 3 ", " 4 " and " $\mathrm{S}$ " again form one group which is significantly different from the combination " 0 ", "1" and " 2 ".

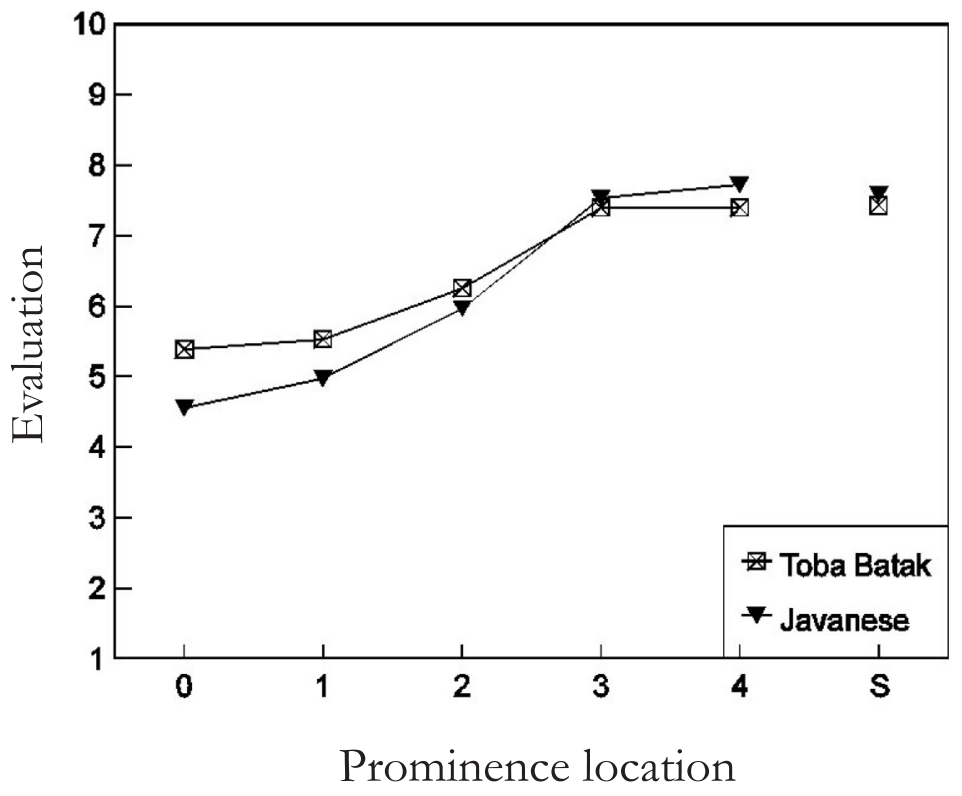

Figure 4: Javanese-based stimuli. Evaluation scores for all prominence locations, broken down by substrate listener group.

The results from our acceptability test corroborate the findings from Section 5.1.1: prominence in Indonesian, as spoken by the Javanese speaker, is acceptable on either the final or the penultimate syllable. Such variation suggests that Javanese Indonesian has free stress, which is, as we explained above, the same as having no stress at all. Let us consider this possibility. If stress is absent in Javanese Indonesian, this should influence the way in which speakers of Javanese Indonesian perceive stress in other varieties of Indonesian. It would, therefore, be interesting to test their reactions to a form of Indonesian that does have "real" stresses. As we have seen in the production experiment, this label may almost certainly be applied to the variety spoken by the Toba Batak speaker. Hence we used that speech to test our hypothesis with respect to the stress perception of Javanese listeners. To confirm whether we were dealing with "real" stresses in our experiment, we included the Toba Batak listeners (who may be looked upon as the expert judges of Toba Batak stress) in this part 
of the experiment as well. Let us see how the subjects reacted to these stimuli. 3.2 TOBA BATAK-BASED STIMULI

\subsubsection{COMPARISON EXPERIMENT}

With the manipulated stimuli based on Toba Batak speech, we also conducted the comparison experiment in which listeners had to select the better one of a pair of two (see 5.1.1.). Figure 5 presents the results in the fashion of Figure 3. Let us first consider the Toba Batak listeners. The figure shows that they prefer prominent penultimate syllables. The percentage score for prominence on the penultimate syllable is clearly higher than all the other scores.

We interpret this result as a reflection of the Toba Batak stress rule in Indonesian spoken by the Toba speaker. It seems that the Toba listeners prefer penultimate stress when listening to a Toba Batak speaker's Indonesian. We will come back to this issue in the general discussion.

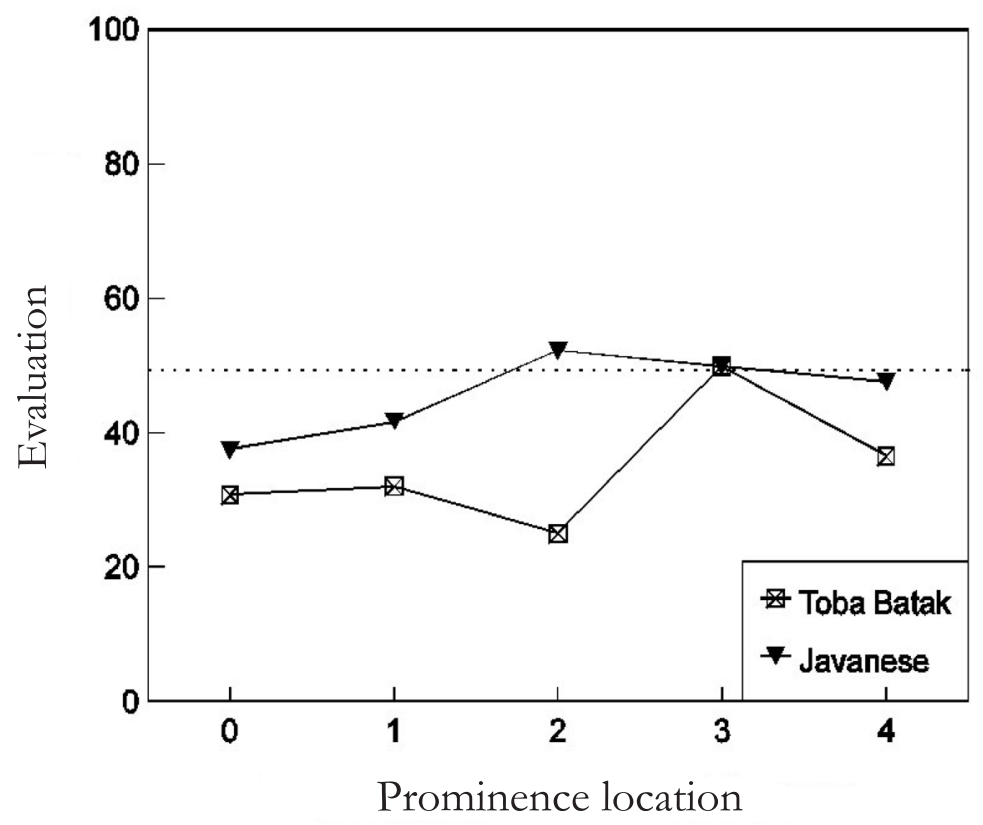

Figure 5: Toba Batak-based stimuli. Percentage of cases in which the stimulus with non-penultimate prominence (Scomp) was judged better than the one with penultimate prominence. Broken down by prominence location and substrate listener group.

The Javanese listeners' reaction to the Toba Batak speech is quite different. Crucially, the percentage scores for all prominence positions are much closer together than is the case for the Toba listeners. The largest difference we may observe lies between positions " 2 " and " 0 " (prominence on the second syllable of the target word and prominence on the first syllable of káta). The scores for all the syllables in the target word are more or less equal " " 1 " is slightly, but not significantly, lower). It seems that Javanese listeners have 
no clear preference for a particular prominence location when they listen to Toba Batak speakers. Any syllable is acceptable. Of course, we again use an acceptability test to see whether the listeners' acceptability scores reflect this striking observation.

\subsubsection{ACCEPTABILITY TEST}

The acceptability scores for the Toba Batak-based stimuli are shown in Figure 6 , again for our two groups of listeners. The preference for the prefinal syllable by the Toba Batak listeners, which we found in the comparison test seems to be confirmed by the high score for this syllable (7.5), but the difference with the scores for the other syllables is rather small.

The acceptability scores of the Javanese listeners resemble quite closely the results we found in the comparison test for these listeners. The rating for prominence on the second syllable is again somewhat higher than the others, but this difference is not significant. Apparently, Toba Batak style stresses are equally acceptable to Javanese ears on whatever syllable in the word they are placed.

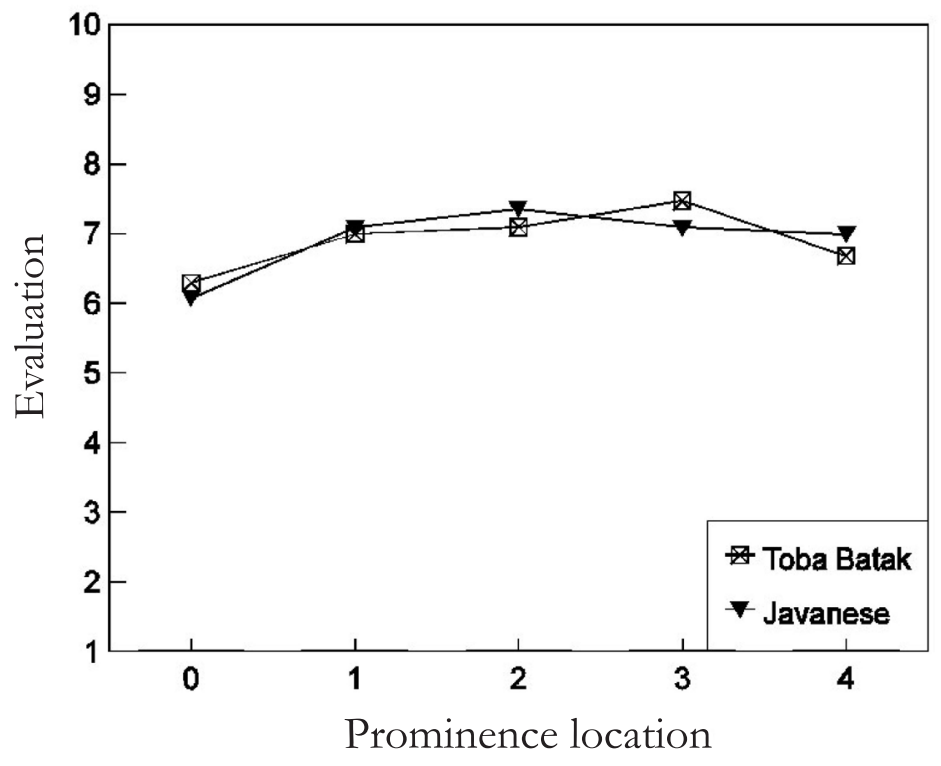

Figure 6: Toba Batak-based stimuli. Evaluation scores for all prominence locations, broken down by substrate listener group.

\section{DISCUSSION}

\subsection{THE STATUS OF WORD STRESS IN INDONESIAN}

The results presented in the previous sections are of crucial importance to the discussion on the status of word stress in Indonesian. In Figures 3 and 4, we have seen that both Javanese and Toba Batak speakers clearly judge both prominence on the prefinal and the final syllable to be acceptable in the speech of the Javanese speaker. Figures 5 and 6 show that the Javanese 
listeners have no preference for a particular prominent syllable in the speech of the Toba Batak speaker, while the Toba Batak listeners themselves prefer the penultimate syllable in this case.

Remember from Section 1.1, that if stressing is very weak, or not detectable by phonetic cues at all, we can only find the stressed syllable by looking at the place where the accent normally docks (Ladd 1996). If accent always aligns to the same syllable, we have found the stress location. It appears, however, that in the variety of Indonesian as spoken by Javanese speakers, accent is not associated with one particular syllable, and may vary between the two last (and even other) syllables for any given word. Consequently, we must conclude that the Javanese variant of Indonesian does not have word stress. It is not overtly realised with phonetic cues, and it does not serve as a docking site for accent. The Toba Batak speech, on the other hand, contained rather canonical stresses, realised by greater intensity and longer duration as well as pitch movement. These properties suggest that we must look upon the Toba Batak stress as a "real" one.

When we look at the way in which the Javanese and the Toba Batak listeners perceived each other's prosodic patterns, we find corroboration of our claim that Javanese style Indonesian does not have stress. When we keep in mind the crucial distinction between accent and stress that we introduced in Section 1.1, we can explain the differences in the reactions of these two groups to our stimuli. The Toba Batak listeners correctly rejected Toba-Batak based stimuli in which stress was not penultimate. They did so because they are used to hearing stresses in strictly defined positions (mostly penultimate) in their own language, and would no doubt also reject stimuli with stress on the initial or second syllable in that language. The Javanese listeners reacted quite differently and did not reject any of the stimuli with alternative stress locations for the Toba Batak speech. They either could not hear, or did not care, on which syllable the Toba Batak stress properties were realised. We can simply say that stress has no meaning to them, which is all the more reason to assume that word stress is neither a feature of Javanese nor of the Javanese variant of Indonesian.

Considering the reactions of the two listener groups to the stimuli based on the speech of the Javanese speaker, we observe that Javanese listeners do seem to be sensitive to intonation. They clearly prefer the pitch movements in their own variety of Indonesian to occur at the right side of the word, and acceptability ratings go down as the pitch movement edges further to the left side of the word. No location is totally unacceptable, however. The reaction of the Toba Batak listeners to these stimuli is striking. Since their own language predominantly has penultimate stresses, and they clearly prefer penultimate stress in their own variety of Indonesian, we expected them to perceive the Javanese intonation pattern as a stress and, therefore, reject all stimuli in which this "stress" did not occur on the penultimate syllable. They did not behave as expected. In fact, they mirrored the behaviour of the Javanese listeners in accepting a pitch movement on the final as well as the prefinal syllable. We suspect that these Toba Batak listeners enter a different "mode" when they 
are confronted with speech from the group of speakers that defines (through group size, but also through greater influence in politics and the media) the most common form of Indonesian. We should mention here that all but one of the Toba Batak listeners lived in Jakarta.

With respect to stress there seems to be no single iron-clad rule for Indonesian. A long history of debates on the exact location of stress indicates to us that no uniform rule can be found. To this evidence, we can now add the tale-telling differences in the reactions of listeners with different substrate backgrounds to different varieties of Indonesian. Speakers from other regions will speak Indonesian with other prosodic patterns, and perceive our stimuli with other ears yet again. However, should we be forced to select one particular pattern as the pattern for Indonesian, it would be the pattern that is adopted by the influential Javanese speakers. This choice is motivated by the fact that the Toba Batak listeners react to the Javanese variant of Indonesian in the same way the Javanese themselves do.

Summarizing, we have found: 1 . indifference of Javanese listeners to Toba Batak word-stress location, and 2. that penultimate and final Javanese-style prominence are acceptable to both groups of listeners. Should we indeed use the label "Indonesian" for its most common variant, Javanese Indonesian, we can state in conclusion that our two main findings do not corroborate the claim that Indonesian has penultimate stress. On the contrary, the data we have gathered in these experiments forcefully refute the claim that stress is penultimate in Indonesian. Quite the opposite is true; we have found compelling evidence for the claim that the most common and influential variant of Indonesian does not have stress at all. However, the occurrence of audible pitch movements does suggest that this variant of Indonesian makes use of accents. But what type of accent are we dealing with here? Surely, it is unlike the standard variety that we have introduced in Section 1.1, since it does not align to a stressed syllable, showing within-word variation with respect to its location at the right word edge. In the next section we will discuss this further.

\subsection{ACCENT OR BOUNDARY TONE?}

With the assumption that Javanese Indonesian prominence may represent accents that are not tied to stressed syllables, we have left the domain of the word-level phenomena. The domain of the accent is, by default, the phrase. Only in special circumstances can that domain be smaller than the phrase, as we have seen in the introduction. In this section, we will present some speculative proposals, based on the premise that Javanese Indonesian prosodic patterns are phrase-level phenomena. We do not expect this section to close the case on Indonesian prosody. On the contrary, much more research into the prosodic system of Indonesian is needed, and we hope that this article forms an incentive for other researchers to carry out that research.

If we assume we are dealing with a phrase-level phenomenon in Javanese Indonesian, we can easily explain the behaviour of our listener groups. The 
judgements of the Toba Batak listeners changed dramatically when they were listening to the Javanese stimuli. In that "mode" (see above), they were no longer judging stress (as in their own language, or the Toba Batak variety of Indonesian) but phrasal intonation. This should not prove to be too difficult for Toba Batak speakers, since they are often exposed to the Javanese variant of Indonesian, and, moreover, they have proven to be quite sensitive to differences in pitch movements (Van Heuven and Van Zanten 1997). The Javanese listeners, on the other hand, could not judge the Toba Batak wordlevel stresses. Remember the indifference to Toba Batak stresses we revealed for the Javanese listeners. This may well result from the fact that Javanese listeners are not used to perceiving stresses at all. They are commonly exposed to phrase-level patterns only and some subjects even told us that the stresslike pitch movements sounded "too harsh" to them.

So, the prominence pattern we perceive in Javanese Indonesian, which we called an accent when we still assumed there was a stressed syllable for this accent to link to, is now a "floating" accent, in the sense that it roams freely at the phrase level because a prescribed docking site is lacking. This is not necessarily a problem. As we have seen in the introduction, accents cán occur on syllables other than the stressed one and the existence of languages in which accents never link to stressed syllables cannot be a priori denied by reason of these being theoretically impossible. We assume such languages have phrasal accents only. If we put the two observations reported above in a new light we do find some evidence that the phenomenon at hand is indeed truly phrasal.

Firstly, the acceptability of prominence in Javanese speech rises as it occurs further towards the right edge of the phrase-final word. Such a gradual rise in acceptability cannot be linked to a word-level phenomenon, but it fits in well with the notion of a phrasal phenomenon that is not bound to a particular syllable and should occur somewhere near the right edge of the phrase. Secondly, the location of the pitch movement is not exactly aligned to a syllable position. In our production experiment we found many cases in which the pitch fall occurred somewhere in between the penultimate and the final syllable. Some of these cases formed the basis for the stylized versions ("S") of the words we included in the stimuli of the experiments. These stylized versions were invariably judged as good as the stimuli in which the pitch fall was clearly located on either the penultimate or the final syllable. ${ }^{5}$ Inexact alignment to syllables is, in our view, indicative of a prosodic phenomenon that does not take place at the level of the word.

However, the arguments above only help us to maintain the claim that

5 According to Suparno (1993: 70-71) there is a difference in meaning depending on the position of the accent in the word. When the accent is on the final syllable, there is a causal relation with another utterance, but when the accent is on the penultimate syllable there is no such causal relation. In a perception experiment Laksman (1996; see also Laksman and Van Heuven 1999) found a correlation between accented final syllables and the perception of anger. Unfortunately, we have no data on the exact position of the accent-lending pitch movement in these cases. 
the phenomenon we are investigating takes place at the phrase level. We can provide no evidence for the claim that what we are dealing with here is accent at all. Should there be no alternative, we could assume to be dealing with accent by default, but, in fact, there is such an alternative. It can be found in an intonation phenomenon called boundary marking. We already noted that the "accentual" pitch movement in Indonesian is typically located on the last word of the phrase. This means that it always occurs in much the same position as the pitch movement that marks the end of the phrase: the boundary tone (Pierrehumbert and Hirschberg 1990). To complicate matters further, it seems that the distinction between accentual and boundary marking intonation movements is very difficult to make in Indonesian. Ebing (1997), who compared discrimination of accent and boundary marking by Indonesian and Dutch subjects, notes that "crucially, there was a substantial interdependence between accent and boundary perception" and "boundarymarking and accent-lending functions are less distinct in Indonesian than in Dutch" suggesting that "this difference reflects a typological difference between languages with a phrasal accent rather than lexical stress - here represented by Indonesian on the one hand, and languages with both lexical stress and accent - here represented by Dutch - on the other" (Ebing 1997: 111113). More recently, Roosman (2006: 18) claimed that accent and boundary marking coincide in Indonesian. In French also, it is difficult to distinguish between accentual and boundary marking pitch movements. Beaugendre (1994: 118) claims that the French accent ("accent fixe") in principle has a demarcative function.

In the light of the above, we should consider the possibility that Indonesian does not make use of two separate phrasal phenomena, namely accent and boundary marker, at all. With respect to the necessary choice for either the one or the other that follows from adoption of that possibility, it is tempting to claim that the prosodic pattern we observe in Indonesian functions as a boundary marker, rather than as an accent. Let us explain why we prefer the former over the latter.

First of all, there is the functional explanation. In stress languages, word stress can have several functions. For instance, if in a language the stress is in a fixed position in the word, it will cue the beginning or end of words in the speech chain. In this way, stress can help the listener to segment continuous speech into discrete units (words). The question may then be raised how listeners of a non-stress language like Indonesian keep track of words in the stream of speech. This is where the phrasal boundary marking comes in. The use of phrase-final pitch movements should help listeners segment the speech stream into discrete short phrases. In addition, pre-boundary lengthening is expected to occur at phrasal boundaries, providing the listener with more time to (re)segment the words in the phrase. Functionally, therefore, the Indonesian prominence pattern seems to be a boundary marker, rather than a (phrasal) accent.

Languages from the Indonesian area seem to split up utterances in 
rather short phrases, which are marked off by clearly perceptible prosodic boundaries. Many examples can be found in Rahyono $(2003,2007)$, Sugiyono $(2003,2007)$, Roosman $(2006,2007)$, and Stoel $(2005,2006,2007)$. Clearly, the shorter the phrase, the easier it will be to distinguish individual words within that phrase.

It is also worth mentioning that word order is fairly restricted in Indonesian languages. The restricted word order probably also contributes to speech perception and understanding. The communicatively most important word typically occurs at the end of the phrase. In the speech of our Javanese speaker the onset of this phrase-final word was often enhanced by a small pitch rise on the word-initial syllable, thus warning the listener that the end of the phrase is near. At the end of this phrase-final word a pitch fall and lengthening cooccur, rendering the phrasal boundary clearly perceptible.

Further evidence for this comes from related languages. Signaling of phrasal boundaries seems very common in other languages in the area, like Jakartan Malay, see Roosman 2006. In his analysis of Banyumas Javanese intonation, Stoel (2006) uses only boundary tones, reasoning that as there are no stressed syllables in this language, there are no pitch accents either. In the Banyumas Javanese final pitch movement, the fall "is typically aligned with the penultimate or final syllable, but it is sometimes difficult to determine its exact position, as this tone is often realized very weakly".

In many other languages, not only in the Indonesian area, phrase-boundary marking is important. In addition, interestingly, there is a general tendency in the world's languages to mark the end of the phrase. For instance, in many Bantu languages, the penultimate syllable of the phrase is 'stressed' (Hyman 1977). Such phrasal-boundary marking reminds us of the boundary marking of words ('demarcative function' of stress) in stress languages. In the majority of stress languages, stresses occur at the right-hand side of the word. All over the world, the penultimate syllable is preferred as the location for stress (Goedemans and Van Zanten 2007: 67). Apparently, knowing where a word or phrase ends (and thus where the next word or phrase will start) is important in speech communication (for a psycholinguistic explanation see Van Heuven and Vermeulen 1981).

Finally, it is important to note once more that, in Indonesian, there is no need for conspicuous accent-lending pitch movements to place words in focus. In principle, the word that is in focus is predictable: it is the final word in the phrase. ${ }^{6}$ Hence, the Indonesian listener can usually infer focus from sentence structure. No focus marking by means of pitch seems to be needed. All in all, we believe there is enough evidence allowing us to look upon the prototypical Indonesian phrasal intonation as boundary marking, rather than

6 After the focalized constituent a reduced contour may follow which contains a defocalized ('retracted') constituent (Halim 1974: 115-117, 125). Such a reduced contour elsewhere called ekor 'tail', see Suparno (1993: 71-83) - is spoken on a low pitch (no accents are permitted in the tail). See also Stoel $(2005,2007)$ on Manado Malay. 
as stress or accent.

We note here that these views are compatible with our observation that the boundary-marking pitch movement occurs mostly, but not necessarily, on the penultimate syllable. Note that the final part of the intonation contour we observed in our data consists of a high pitch level followed by a fall, to then end on a low pitch. It is the change in pitch (from level to falling) that we perceived as an accent (and which some have interpreted as stress in the past). Remember that, whatever we may call them, these elements are all part of the Indonesian utterance-final phrase-boundary marker we postulate. If we take that into account, we may explain the predominance of penultimate-syllable prominence as a statistical effect. In a language where "accent" alignment is in principle free, the low end of the intonation contour aligns to the end of the utterance-final word. It is to be expected that, by default, the contour aligns such that most of the fall occurs on the final syllable, while it starts on the prefinal syllable; the simple reason being that the fall needs space to be expressed, but normally should not use more space than is strictly necessary. The point is that this is only a tendency. The start of the fall (high pitch point) that would indicate the pitch accent in English and Dutch (and must align to the stressed syllable of the prosodic head in those languages, however far from the word edge this syllable occurs) may freely occur to the left or right of the penultimate syllable in Indonesian. In those cases, the duration of the fall is simply lengthened, or shortened, respectively. Such statistical considerations might also explain the observations of Van Zanten and Van Heuven (2004), who note that prefinal closed syllables "seem to attract stress". That might simply be so because of the longer duration of such prefinal syllables, which makes it more likely that the starting point of the fall occurs there.

\subsection{A PERSISTENT “RULE”}

Now that we have concluded that Indonesian does not have word stress, we may wonder what to think of claims to the contrary. The fixation on stress as an unavoidable prosodic phenomenon that is characteristic of contemporary linguistics in the West has translated itself in the adoption of very detailed stress patterns (even with specific rules for secondary stresses, that is Cohn and McCarthy 1994) for Indonesian. We believe that these stress patterns do not represent the Indonesian language as a whole, but may reflect certain regional varieties. There is no doubt that regional variation in the prosodic patterning used in Indonesian exists. As we have seen in our data, the Toba Batak word-prosodic pattern is very different from that found in Javanese. Prentice (1994), operating under the assumption that all varieties use stress, notices some trends. He divides the Indonesian speaking world into two regions: an 'Eastern' region (Java, Sulawesi and eastward), where stress falls on the penultimate syllable of the word regardless of any suffixes, and a 'Western' region (Kalimantan, Sumatra), where suffixation does not induce a rightward stress shift. In the same vein, Tadmor (1999, 2000, cited in Gil (2006)) mentions a tendency for word stress in Malay/Indonesian to progress from final, in the 
western parts of the archipelago, towards penultimate, in the eastern regions, reflecting a similar progression in the local languages.

Undoubtedly, we will need stress rules to describe some of these varieties, but we must be ready to abandon such stress-oriented descriptions for others if the alternative is theoretically less taxing, and the observations (preferably resulting from empirical research) reveal that stress has neither a linguistic function, nor any meaning to the speakers of the variety in question.

A case in point may be Riau Indonesian. According to Gil (2006) Riau Indonesian is a strongly isolating language; the typical word is disyllabic, but there are also monosyllabic words and words of more than two syllables. If a (disyllabic) word is in [+focus] position, both syllables are marked by pitch prominence and they are lengthened considerably (the penultimate syllable more so than the final one). Guided by these observations of the Riau prosodic pattern, Gil makes a remarkable claim. Instead of a 'privileged syllable which could be characterized as the locus of word stress', he posits a 'privileged disyllabic unit' or 'core foot', which is the bearer of word stress in Riau Indonesian.

Instead of introducing theoretical novelties, we prefer to accept the fact that languages may lack word stress altogether. In our view, associating lengthening and pitch prominence to more than one syllable, are tell-tale signs of phrasal phenomena, like phrasal accents or boundary tones. We suggest, therefore, that Riau could be analysed as a non-stress Malay variety. As such, it would fit a pattern that is more common to the area than contemporary metrical theory would have it. As Gil (2006) notices himself, similar phonetic effects can be found in languages other than Riau. Phonetic effects we have observed in several (Indonesian) languages seem to confirm this.

Of course, we cannot be certain that Riau Indonesian is a non-stress language before solid evidence is gathered by careful experimentation: if syllable lengthening was found to consistently occur on predictable (single) syllables in [-focus] position, that would indicate that Riau does have wordbased stress. If that is not the case, an interesting topic for future research may be to find out whether the Riau pitch movements should be seen as phrasal accents or as boundary tones.

The Riau case shows how difficult it is to abandon traditional stress analyses, even though there is ample evidence that claiming the absence of word-level stress for a language does by no means make it a theoretical isolate. Haspelmath, Dryer, Gil, and Comrie (2005) estimate that four percent of the world's languages have no rule-based word-prosodic system at all, ${ }^{7}$ but the percentage of non-stress languages may be larger. For instance, many of the Bantu languages of sub-saharan Africa also seem to lack word-based stress, while in Europe, French is considered to be a non-stress language. In the Indonesian area, Jakartan Malay (Roosman 2006) and Banyumas Javanese 
(Stoel 2006) do not have word-based stress. Also, Lynch, Ross, and Crowley (2002) state that three of the 43 Oceanic languages they researched appear to have no word-based stress, and that there are probably more. In many of these languages, phrases seem to be communicatively important.

So, why then is it that researchers have claimed for so long that Indonesian does have stress? First of all, it may be that, as we have noted above, the variety that they were looking at does really have stress. Yet, even if they researched a variety that does, in our view, not have stress, they may claim it, for several reasons.

First, it should be mentioned that mainly non-native speaker linguists have upheld the penultimate-stress rule for Indonesian. Others, like Halim (1974), have denied the existence of stress in their language long ago. These foreign linguists may fall prey to several tricks their ears can play on them. Let us look into these more carefully.

Indonesian stress has often been called weak by Dutch researchers. We have seen such weak utterance-final pitch movements in our Javanese material. Actually, Indonesian listeners prefer small pitch movements to larger ones (Van Zanten and Van Heuven 2004). Similarly, Stoel (2006) describes rather small phrase-final pitch excursions for Banyumas Javanese in sentences with final focus. "Since this is the default focus structure in Javanese, there is no need to mark it explicitly".

Speakers of stress languages, on the other hand, use fairly large prominencelending pitch movements; for an average Dutch speaker, accent-lending rises need to be quite a bit larger than the small pitch movements that Indonesians generally prefer.

To confuse matters, large pitch movements do also occur in for instance Indonesian/Jakartan Malay (Roosman 2006), as well as in Banyumas Javanese (Stoel 2006). These (utterance-medial) large pitch movements may in the past have been interpreted as stresses, while in fact they are not associated with words but with phrases, signaling phrasal boundaries. It is not surprising that western researchers have (wrongly) interpreted these pitch movements as stresses. Since they use stress in their own language, they tend to perceive pitch movements in foreign languages - to which they are, unlike our Toba Batak informants, not exposed on a daily basis - as stresses also. The fact that Indonesian languages often have short phrases, sometimes consisting of one word only compounds the effect. This makes it even more difficult to distinguish between (word) stresses and (phrasal) accents or boundary tones.

There is another effect that makes it difficult to determine stress position (if it exists) in varieties of Indonesian. This has to do with a prosodic phenomenon known as "final lengthening": elements just before a prosodic boundary are longer (all else being equal) than elements occurring closer towards the beginning of a word. In disyllables, which are quite common in the languages of the Indonesian area, this final lengthening effect is hard to distinguish from any occurring prominence effects. This is the reason why we used longer (4-syllable) words in our experiments. 
Finally, words like bantuan, with a nasal at the end of the first syllable, often seem to have a stressed first syllable (Goedemans and Van Zanten 2007; Van Zanten and Van Heuven 2004). In fact, this first syllable is probably only perceived as long because it consists of three (ban-) rather than the usual two $(-t u-,-a n)$ phonemes. Our experiments show that this cannot have anything to do with stress position, but the effects may have easily confounded the ears of western linguists, giving them the impression to be dealing with a common stress language, while in fact, the native speakers' perception tells a different story.

\section{CONCLUSION}

The most important conclusion we draw from the results of our experiments is that there is no reason whatsoever to assume that there is such a thing as word-based stress in Indonesian. We have shown that speakers with different substrate languages behave differently with respect to 'stress' realization and perception. Even if we set this caveat aside, however, and concentrate on the variety spoken by the most dominant substrate group (Javanese), we conclude that there is good reason to exclude the penultimate stress hypothesis. In our view, the rule that drives prominence patterns in the influential Javanese variety of Indonesian is phrasal. Probably, the only phonological rule that is relevant for prominence location in Indonesian states that it must occur somewhere at the right edge of the phrase.

In stress languages, one of the functions of stress is to help listeners to recognize individual words in the stream of speech. Hearing a stress will inform the listener that a (content) word has started or ended. We hypothesize that phrase-boundary marking helps listeners of a non-stress language to keep track of words in the speech flow. Impressionistically, it seems that non-stress languages have rather short and clearly marked phrases. The readily perceptible phrasal boundaries help the listener to parse continuous speech, and the short phrases are easy to segment into words. In this way, the speech-segmenting function exercised by means of word stress in most languages can also be exercised through phrasal boundary markers. These markers, then, have a clear function in (Javanese) Indonesian, whereas stresses and accents do not.

\section{REFERENCES}

Abott, S. 1985. "A tentative multilevel multiunit phonological analysis of the Murik language", Papers in New Guinea Linguistics 22: 339-373. [Pacific Linguistics A 63.]

Alieva, N.F., V.D. Arakin, A.K. Ogloblin, and Yu.H. Sirk. 1991. Bahasa Indonesia; Deskripsi dan teori. Yogyakarta: Kanisius.

Beaugendre, F. 1994. “Une étude perceptive de l'intonation du Français”. PhD thesis, Université Paris XI.

Berinstein, A.E. 1979. "A cross-linguistic study on the perception and 
production of stress". [UCLA Working Papers in Phonetics 47, University of California.]

Bolinger, D. 1958. "A theory of pitch accents in English", Word 14: 109-149.

Bolinger, D. 1972. "Around the edge of language; Intonation", Intonation, Penguin modern linguistic readings, pp. 19-29. Harmondsworth: Penguin.

Cohn, A. 1989. "Stress in Indonesian and bracketing paradoxes", Natural Language and Linguistic Theory 7: 167-216.

Cohn, A. and J.J. McCarthy. 1994. "Alignment and parallelism in Indonesian phonology", ROA-25.

Ebing, E.F. 1997. Form and function of pitch movements in Indonesian. Leiden: CNWS, Leiden University. [CNWS publications 55.]

Eefting, W.Z.F. 1991. "The effect of information value and accentuation on the duration of Dutch words, syllables and segments", Journal of the Acoustical Society of America 89: 412-414.

Foley, W. A. 1991. The Yimas language of New Guinea. Stanford: Stanford University Press.

Fry, D.B. 1955. "Duration and intensity as physical correlates of linguistic stress", JASA 27: 765-768.

Fry, D.B. 1958. "Experiments in the perception of stress", Language and Speech 1: $126-152$.

Fry, D.B. 1965. "The dependence of stress judgements on vowel formant structure", Proceedings of the fifth ICPhS, Munster 1964, pp. 306-311. Basel/New York: S. Karger.

Gil, D. 2006. "Intonation and thematic roles in Riau Indonesian", in: C.M. Lee, M. Gordon, and D. Büring (eds), Topic and focus; Cross-linguistic perspectives on meaning and intonation, pp. 41-68. Dordrecht: Springer. [Studies in Linguistics and Philosophy 82.]

Goedemans, R.W.N., H.G. van der Hulst, and E.A.M. Visch. 1996. Stress patterns of the world; Part 1: Background. The Hague: Holland Academic Graphics. [HIL Publications 2.]

Goedemans, R.W.N. and E. van Zanten. 2007. "Stress and accent in Indonesian", in: V.J. van Heuven and E. van Zanten (eds), Prosody in Indonesian languages, pp. 35-62. Utrecht: LOT (Netherlands Graduate School of Linguistics). [LOT Occasional Series 9.]

Halim, A. 1974. Intonation in relation to syntax in Bahasa Indonesia. Jakarta: Djambatan.

Haspelmath, M., M. Dryer, D. Gil, and B. Comrie. 2005. The world atlas of language structures. Oxford: Oxford University Press.

Hayes, B.P. 1995. Metrical stress theory; Principles and case studies. Chicago: University of Chicago Press.

Heuven, V.J. van. 1994. "Introducing prosodic phonetics", in: C. Odé and V.J. van Heuven (eds), Experimental studies of Indonesian prosody, pp. 1-26. Leiden: Vakgroep Talen en Culturen van Zuidoost-Azië en Oceanië, Leiden University. [Semaian 9.]

Heuven, V.J. van and M.P.R. van den Broecke. 1982. “Interactions of spectral 
distribution and decay time in the auditory perception of duration and their relevance to speech", Progress Report of the Institute of Phonetics Utrecht $7: 1,21-41$.

Heuven, V.J. van and J.F.M. Vermeulen. 1981. "De plaats van klemtoon en accent in de auditieve woordherkenning: hoe eerder hoe beter?", Verslagen van de 156e vergadering van de Nederlandse Vereniging voor Fonetische Wetenschappen, gehouden to Amsterdam, 16 oktober 1981: 38-53.

Heuven, V.J. van and E. van Zanten. 1997. "Effects of substrate language on the localization and perceptual evaluation of pitch movements in Indonesian", in: C. Odé and W. Stokhof (eds), Proceedings of the seventh International Conference on Austronesian Linguistics, pp. 63-79. Amsterdam/ Atlanta: Rodopi.

Hollander, J.J. de. 1984. Pedoman bahasa dan sastra Melayu. Jakarta: Balai Pustaka.

Horne, E.C. 1961. Beginning Javanese. New Haven: Yale University Press.

Hyman, L. 1977. "On the nature of linguistic stress", in: Larry Hyman (ed.), Studies in stress and accent, pp. 37-82. Los Angeles: Department of Linguistics, University of Southern California. [Occasional Papers in Linguistics 4.]

Ladd, R.D. 1980. The structure of intonational meaning; Evidence from English. Bloomington: Indiana University Press.

Ladd, R.D. 1996. Intonational phonology. Cambridge: Cambridge University Press.

Laksman, M. 1994. "Location of stress in Indonesian words and sentences", in: C. Odé and V.J. van Heuven (eds), Experimental studies of Indonesian prosody, pp. 108-139. Leiden: Vakgroep Talen en Culturen van ZuidoostAzië en Oceanië, Leiden University. [Semaian 9.]

Laksman, M. 1996. “Pengaruh perbedaan sistem prosodi dua bahasa terhadap persepsi emosi". [Research Report FSUI, Depok.]

Laksman, M. and V.J. van Heuven 1999. "Perception of emotion in Indonesian by native and foreign listeners". Paper, The third Symposium on Malay/ Indonesian Linguistics, Amsterdam, 24-25 August.

Lynch, J., M. Ross, and T. Crowley. 2002. The Oceanic languages. Richmond: Curzon.

Nababan, P.W.J. 1981. A grammar of Toba Batak. Canberra: SPAS. [Pacific Linguistics D 37.]

Nooteboom, S.G. 1972. "Production and perception of vowel duration; A study of durational properties of vowels in Dutch". PhD thesis, Utrecht University.

Percival, W.K. 1981. A grammar of the urbanised Toba-Batak of Medan. Canberra: RSPAS. [Pacific Linguistics B-76.]

Pierrehumbert, J. and J. Hirschberg. 1990. The meaning of intonational contours in the interpretation of discourse, in: P.R. Cohen, J. Morgan, and M.E. Pollack (eds), Intentions in communication; System development foundation benchmark series., pp. 271-311. Cambridge MA: MIT press. 
Poedjosoedarmo, S. 1982. Javanese influence on Indonesian. Canberra: RSPAS. [Pacific Linguistics D 38.]

Prentice, J. 1994. "Manado Malay; Product and agent of language change", in: T. Dutton and D.T. Tryon (eds), Language contact and language change in the Austronesian world, pp. 411-441. Berlin/New York: Mouton de Gruyter. [Trends in Linguistics 7.]

Rahyono, F.X. 2003. "Intonasi ragam bahasa jawa keraton Yogyakarta: kontras deklarativitas, interogativitas, dan imperativitas". PhD thesis, University of Indonesia.

Rahyono, F.X. 2007. "Intonation of the Yogyakarta palace language", in: V.J. van Heuven and E. van Zanten (eds), Prosody in Indonesian languages, pp. 177-189. Utrecht: LOT (Netherlands Graduate School of Linguistics). [LOT Occasional Series 9.]

Ras, J.J. 1982. Inleiding tot het modern Javaans. Den Haag: Nijhoff.

Roosman, L.M. 2006. Phonetic experiments on the word and sentence prosody of Betawi Malay and Toba Batak. Utrecht: LOT. [LOT Dissertation Series 129.]

Roosman, L.M 2007. "Melodic structure in Toba Batak and Betawi Malay word prosody", in: V.J. van Heuven and E. van Zanten (eds), Prosody in Indonesian languages, pp. 89-115. Utrecht: LOT (Netherlands Graduate School of Linguistics), 89-115. [LOT Occasional Series 9.]

Samsuri. 1971. Ciri-ciri prosodi dalam kalimat Bahasa Indonesia. Flores: Nusa Indah.

Samsuri. 1978. "Fokus dan alat-alat pembentukannya dalam Bahasa Indonesia". [Unpublished ms.]

Steinhauer, H. 2001. Leerboek Indonesisch. Leiden: KITLV Uitgeverij.

Stoel, R.B. 2005. Focus in Manado Malay; Grammar, particles, and intonation. Leiden: CNWS.

Stoel, R.B. 2006. "The intonation of Banyumas Javanese", Proceedings Speech Prosody 2006, pp. 827-830. Dresden: TUD Press.

Stoel, R.B. 2007. "The intonation of Manado Malay", in: V.J. van Heuven and E. van Zanten (eds), Prosody in Indonesian languages, pp. 117-150. Utrecht: LOT (Netherlands Graduate School of Linguistics). [LOT Occasional Series 9.]

Sugiyono. 2003. "Kajian psikoakustik terhadap frekuensi fundamental pada kontras deklarativitas dan interogativitas". PhD thesis, University of Indonesia.

Sugiyono. 2007. "Prosodic markers of the statement-question contrast in Kutai Malay", in: V.J. van Heuven and E. van Zanten (eds), Prosody in Indonesian languages., pp. 151-175. Utrecht: LOT (Netherlands Graduate School of Linguisitcs). [LOT Occasional Series 9.]

Suparno. 1993. Konstruksi tema rema dalam Bahasa Indonesia lisan tidak resmi masyarakat kotamadya Malang. Jakarta: PPPB.

Tadmor, U. 1999. "Can word accent be reconstructed in Malay?". Paper, the Third International Symposium on Malay/Indonesian Linguistics, 
Amsterdam, 24 August.

Tadmor, U. 2000. "Rekonstruksi aksen kata Bahasa Melayu", in: Yassir Nasanius and Bambang Kaswanti Purwo (eds), PELBRA 13, Pertemuan Linguistik (Pusat Kajian) Bahasa dan Budaya Atma Jaya Ketiga Belas, pp. 153-167. Jakarta: Pusat Kajian

Bahasa dan Budaya, Unika Atma Jaya.

Teeuw, A. 1984. Leerboek Bahasa Indonesia. Groningen: Wolters-Noordhoff.

Woodrow, H. 1951. “Time perception", in: S. Stevens (ed.), Handbook of experimental phonology, pp. 1224-1236. New York: Wiley and Sons.

Zanten, E. van and R.W.N. Goedemans. 2007. "A functional typology of Austronesian and Papuan stress systems", in: V.J. van Heuven and E. van Zanten (eds), Prosody in Indonesian languages, pp. 63-88. Utrecht: LOT (Netherlands Graduate School of Linguisitcs). [LOT Occasional Series 9.]

Zanten, E. van, R.W.N. Goedemans, and J.J.A. Pacilly. 2003. "The status of word stress in Indonesian", in: J. van de Weijer, V.J. van Heuven, and H.G. van der Hulst (eds), The Phonological Spectrum; Volume II: Suprasegmental structure, pp. 151-175. Amsterdam/Philadelphia: John Benjamins.

Zanten, E. van and V.J. van Heuven. 1997. “Effects of word length and substrate language on the temporal organisation of words in Indonesian", in: C. Odé and W. Stokhof (eds), Proceedings of the seventh International Conference on Austronesian Linguistics, pp. 201-213. Amsterdam/Atlanta: Rodopi.

Zanten, E. van and V.J. van Heuven. 2004. “Word stress in Indonesian; Fixed or free?", NUSA 53: 1-20. 